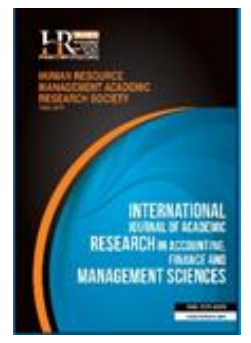

International Journal of Academic Research in Accounting, Finance and Management Sciences

Vol. 8, No.3, July 2018, pp. 299-309

E-ISSN: 2225-8329, P-ISSN: 2308-0337

(c) 2018 HRMARS

www.hrmars.com

To cite this article: Tyasari, I., Yusof, N.Z.M, Ku Bahador, K.M. (2018). Indonesia's Participation in ASEAN Audit Regulators Group (AARG): Efficiency-driven or Institutional Pressure? International Journal of Academic Research in Accounting, Finance and Management Sciences 8 (3): 299-309.

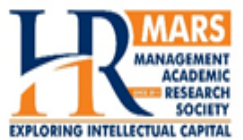

http://dx.doi.org/10.6007/IJARAFMS/v8-i3/4916 (DOI: 10.6007/IJARAFMS/v8-i3/4916)

\title{
Indonesia's Participation in ASEAN Audit Regulators Group (AARG): Efficiency-driven or Institutional Pressure?
}

\author{
Irma TYASARI ${ }^{1}$, Nor Zalina Mohamad YUSOF ${ }^{2}$, Ku Maisurah KU BAHADOR $^{3}$
}

1,2,3Tunku Puteri Intan Safinaz School of Accountancy, Universiti Utara Malaysia, ${ }^{1}$ E-mail: Irmatyasari26@gmail.com

\begin{abstract}
This paper takes institutional theory perspective to discuss the efforts being undertaken by regulators and accounting profession in Indonesia to strengthen its audit quality (AQ). The question being asked is whether Indonesia's participation in ASEAN Audit Regulators Group (AARG), whose aim is to strengthen AQ in ASEAN country, is purely part of the country's on-going efforts on $A Q$ or is it motivated by mimetic pressure to be similar to its neighbours. Using data obtained from various public sources, the paper shows that in comparison with its neighbouring countries Indonesia is behind in terms of few aspects concerning $A Q$ including the number of accountants in the country. However, evidence also shows that the country was putting in various initiatives in relation to its $A Q$ even prior to its joining the AARG in 2014. Although the number of accountants was small relative to its population, the country is in fact seeing significant increase in the number in the last three years prior to its joining the AARG. Indonesia's participation in AARG suggests that the country aims to be at par with its neighbours in terms of $A Q$. Following its participation with AARG, the country has issued a draft of Audit Quality Indicators (AQIs) in 2016 as well as Code of Ethics in 2017 for accountants. Hence, although participation in AARG could initially be motivated by mimetic pressure, the evidence shows that the country is in positive direction in its quest to improve $A Q$.

Key words Audit quality, Institutional Theory, isomorphism, AARG, Indonesia, ASEAN

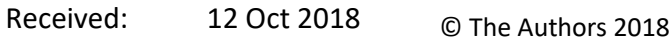

Revised: 22 Oct $2018 \quad$ Published by Human Resource Management Academic Research Society (www.hrmars.com

Accepted: $\quad 30$ Oct $2018 \quad$ This article is published under the Creative Commons Attribution (CC BY 4.0) license. Anyone may Published 22 Nov reproduce, distribute, translate and create derivative works of this article (for both commercial and non-commercial purposes), subject to full attribution to the original publication and authors. The full 2018 terms of this license may be seen at: http://creativecommons.org/licences/by/4.0/legalcode
\end{abstract}

\section{Introduction}

Audit quality (AQ) has become a serious concern in the global accounting profession in recent decades following the series of corporate failures in the US and Europe that drew attention to the role of auditors. In the year 2002, the US's biggest energy firm, Enron, collapsed; bringing together its auditor, Arthur Andersen \& Co. The global accounting landscape changed because of this scandal; the profession that previously enjoyed self-regulations is now being questioned for its effectiveness in meeting their objectives. The Sarbanes Oxley Act (SOX) was then established in 2002 as more cases were exposed including Adelphia Communications in the US and Parmalat in Italy. The establishment of SOX has brought huge impact to the profession. Regulators quickly took actions to revive the tarnished reputation of the profession and considerable efforts have been directed towards improving AQ.

More than a decade later, despite various efforts and measures taken by these parties to enhance $A Q$, it is still very much a concern. In 2015 , for example, a global survey by the International Forum of Independent Audit Regulators (IFIAR) on its 29 members from different jurisdictions finds that audit still unable to provide the level of assurance expected of it by the users of financial statements. More alarmingly, the concern is centered on audit procedures deficiencies with the most deficiencies are also 
those most fundamental to the quality of financial statements (www.ifiar.org). In the same year, the UK Financial Reporting Council (FRC) also published its report on $A Q$ that indicates that although $A Q$ is improving, but there are still rooms for improvements.

As concerns mounted, accounting bodies continue to work towards enhancing the AQ. In January 2016, the US Center for Audit Quality (CAQ), which is affiliated with the American Institute of CPA (AICPA), has published their insights learned from a series of roundtable discussions with various stakeholders to gather their feedback on a potential set of audit quality indicators. This is following their release of the "CAQ Approach to Audit Quality Indicators" (AQI) in 2014 (www.thecaq.org). The AICPA itself has published the "AICPA's Enhancing Audit Quality (EAQ)" initiative in 2014 to address audit quality challenges on a holistic, ongoing basis, with the goal of improving audit performance. A year later, they published the "6Point Plan to Improve Audit Quality" that describes extensive ongoing and new efforts to improve AQ. These initiatives show that $A Q$ is still receiving a significant focus at the global level (www.thecaq.org).

Being part of the global economy, ASEAN countries have also been focusing their attention on the issues of AQ. In 2011, three members of ASEAN, which are Malaysia, Singapore, and Thailand, have taken steps to promote better $A Q$ in the region. The Accounting and Corporate Regulatory Authority (ACRA) of Singapore, the Securities and Exchange Commission (SEC) of Thailand, and the Malaysia's Audit Oversight Board (AOB) - all of which are members of IFIAR, came together and founded the ASEAN Audit Regulators Group (AARG). This informal organization aims to promote $A Q$ in the region through enhanced collaboration between audit regulators. In 2013 Indonesia became a member of IFIAR; and the following year in 2014, it became the fourth member of AARG.

This paper, therefore, aims to discuss the motivation behind Indonesia's participation in AARG. While the underlying rationale for corporate governance have been subject to fair debates in recent years (Jo and Harjoto, 2011; Moore et al., 2012; Aguilera and Jackson, 2010; Adams et al., 2010; Claessens and Yurtoglu, 2013), not much theoretical and empirical debates have been done on the rationale for $A Q$ efforts in emerging economies. Taking the perspective of institutional theory, this paper aims to investigate why a country decides to be part of regional movement on $A Q$ when it itself is still struggling to promote better $A Q$ at home. The paper also seeks to discuss on how this participation helps improve $A Q$ in the country. The analysis will show how, being motivated by mimetic pressure, Indonesia has then progressively improved its $A Q$ in terms of initiatives by accounting regulators.

This paper does not intend to analyze the overall efforts undertaken by Indonesian accounting regulators on $A Q$ in the country; rather, the paper is focusing only on its participation in AARG as part of its attempt to enhance $A Q$. The establishment of AARG and the participation of Indonesia in this organization are considered as relatively recent; hence, it is interesting to provide discussion on how such participation could explain a country's adoption of systems and procedures to improve its chances for survival as advanced by institutional theorists. Furthermore, this paper is organized as follow: the next section discusses the institutional theory framework, regulator's initiatives in enhancing on audit quality. There are then followed by the methodology, findings, and discussion. This paper ends with some concluding remarks.

\section{Literature review}

\subsection{An Institutional Theory Framework}

Institutional theory is useful in providing an explanation for institutional decisions and activities in organizations or countries (Meyer and Rowan, 1977; DiMaggio and Powell, 1983; Covaleski and Dirsmith, 1988; Carruthers, 1995). The theory highlights cultural influences on decision making and formal structures. These cultural elements define the way the world is and should be (Barley and Tolbert, 1991). Hence, institutionalists suggest that organization's survival as suggested by Covaleski et al., 1993. Institutions represent constraints on the options that individuals and organizations are likely to exercise (Barley and Tolbert, 1991). It is defined as "the shared and taken for granted assumptions which identify categories of human actors and their actions.

By bringing in social context, institutional theory shows how organizations and countries are influenced by normative pressures, which lead them to be guided by legitimated elements; hence, leading to isormophism or increasing similarity with the institutional elements for the sake of survival (Zucker, 
1987). The main argument of institutional isomorphism is that organizations conform to "rationalized myths" in society about what constitute a proper organization. As argued by DiMaggio and Powell (1983), in their quest for legitimacy, organizations (in our case a country), are subjected to isomorphic pressures which produce increasing similarity among the organizations or countries over time. They further indicated three pressures that lead organizations to become isomorphic; they are coercive, mimetic, and normative pressures. Coercive isomorphism originates from political influence and the problem of legitimacy; mimetic isomorphism is attributable to standard responses to uncertainty; and normative isomorphism is related to professionalization (DiMaggio and Powell, 1983).

\subsection{The Regulator's Initiatives in Enhancing Audit Quality}

Since the past decade, the regulators have made initiatives in their policies of the auditing profession. The initiative is to develop a perspective on audit quality issues being debated internationally. The goal of the initiatives is to identify solution to address audit quality (Beattie et al., 2010; DeFond and Lennox, 2011; Hecimovic et al., 2009; Knechel, 2016).

Although there is no universally agreed definition of audit quality (Aghaei Chadegani, 2011; Francis, 2011), a useful starting point is the classic audit quality's definition of DeAngelo (1981), in which audit quality is defined as a combination of the probability that the auditor will discover a material misstatement in the client's financial statements and the probability that they will report it. Based on this perspective, audit quality is seen a function both auditor's competence and auditor independence. The competence is shown from the way of auditor to discover the misstatements, while the independence is from the auditor to report them. Therefore, the regulators with their capacities have authorization to prepare the formulation of the policies, guidance, development and supervision of the auditing profession (Humphrey, Loft \& Woods, 2009; Lennox, 2009) to maintain the competency as well the independency, since these both aspects are the factors which influence the audit quality (Gul et al., 2013; Mansouri et al., 2009).

Instead of maintaining and developing the competency and independency program for auditors, the regulators also scaling up the number of accountants. This initiative is considered crucial since the number of auditors which tend to be quite limited, therefore objectivity and independence can be difficult to achieve (DeAngelo, 1981). With a limited number of auditors, the company cannot have opportunity to select high quality of auditor. In addition, this limitation also disrupts the auditor rotation rules work properly. This can lead to a close relationship between the auditor and the client, which affects the independence of the auditor (Jackson et al., 2008; Lennox et al., 2014). The initiatives mentioned above is just part of regulator's initiatives to enhance audit quality, besides other initiatives such as collaborative program among ASEAN countries (www.pppk.kemenkeu.go.id), issuing a new law or regulations (DeFond and Lennox, 2011; Hecimovic et al., 2009), restructuring the regulator's agents (Fearnley et al., 2014), and also adopting new auditing and accounting standards (http://www.ifac.org).

\section{Methodology of research}

In gaining understanding on the motivations for Indonesia's participation in AARG, this study relies on qualitative research method as this is a better approach to investigate the underlying reasons for such decision (Patton, 2002). Table 1 below is the list of data sources of this study.

Table 1. Data sources

\begin{tabular}{|cl|}
\hline No & \\
\hline 1 & Data sources \\
2 & Government's and professional body's website \\
3 & Official report of regulators \\
4 & International institutions' report \\
5 & Press release \\
6 & Newspapers, professional magazine \\
\hline
\end{tabular}




\section{Findings}

As mentioned above that the purpose of this study is to examine whether Indonesia's participation in ASEAN Audit Regulators Group (AARG), whose aim is to strengthen its audit quality in ASEAN country, is purely part of the country's on-going efforts on audit quality or it is motivated by mimetic pressure to be similar to its neighbours. The first point discusses about the collective efforts by ASEAN.

\section{Collective Efforts by ASEAN}

In ASEAN, there are two regional accountancy organizations, which are, the ASEAN Federation of Accountants (AFA) - established in 1977; and the Confederation of Asian and Pacific Accountants (CAPA), established in 1976. However, the discussion on regional efforts will focus more on the efforts done by AARG. This is because, AFA is not formally recognized and acknowledged by IFAC; while for CAPA, although it is recognized by IFAC, only two ASEAN countries are members of this organization (www.aseanaccountants.org). Furthermore, although AARG is made up of only three ASEAN countries, but the involvement in its efforts come from many other countries and relevant parties including audit firms. In terms of membership, while AARG is consists of accounting regulatory bodies of members' country, AFA and CAPA are consisting of the country members' accounting professional bodies. It is also interesting to focus on AARG as it appears very active since its establishment in 2011, and is affiliated to a world organization, International Forum of Independent Audit Regulators (IFIAR).

IFIAR is a global body, established in 2006 by 17 countries; now its membership has reached to 51 . The body consists of independent audit regulators from various jurisdictions around the world. In promoting $A Q$, IFIAR has provided a platform for regulators to share knowledge and practical experience gained from their independent audit regulatory activity. As an affiliation to IFIAR, AARG also has adopted similar approaches to promote $A Q$, which is through discourse. Table 1 below summarizes the initiatives taken by AARG in relation to enhancement of $A Q$ in the region. The annual meeting and Audit Inspection Workshops mirror those conducted by IFIAR (www.ifiar.org).

Table 2. AARG Initiatives

\begin{tabular}{|c|c|}
\hline Activities & Explanations \\
\hline $\begin{array}{l}\text { AARG Annual } \\
\text { meeting }\end{array}$ & $\begin{array}{l}\text { - Annual event attended by AARG members. The first meeting was in } 2011 \text { until the third in } \\
2013 \text { were attended by AARG members only. In 2014, Indonesia attended for the first time as } \\
\text { observer. The } 5^{\text {th }} \text { meeting in } 2015 \text { in Kuala Lumpur attracted a wider participation by } 80 \\
\text { regulators and audit firms from Cambodia, Hong Kong, Indonesia, Laos, and Philippines. } \\
\text { - Also includes dialogue and engagement with Big Four Audit Firms from member countries of } \\
\text { the GPPC firms. } \\
\text { - In 2015, discussion was focused on the use of AQl to spur deeper conversations on AQ } \\
\text { matters between audit firms and stakeholders; as well as the implementation of the new } \\
\text { expanded audit report. }\end{array}$ \\
\hline $\begin{array}{l}\text { AARG Audit } \\
\text { Inspection } \\
\text { Workshop }\end{array}$ & $\begin{array}{l}\text { - Annual event attended by audit regulators from other countries as well (Cambodia, } \\
\text { Indonesia, Laos, Vietnam, Hong Kong, Japan). } \\
\text { - } \quad \text { Facilitate discussion among participants about latest development concerning audit. } \\
\text { - Members deliver their latest development of guidance and supervision of independent audit } \\
\text { regulators and findings of violations that frequently discovered during inspection. } \\
\text { - In 2014, Kuala Lumpur hosted the } 8^{\text {th }} \text { Inspection Workshop of IFIAR. }\end{array}$ \\
\hline $\begin{array}{l}\text { Working with } \\
\text { the World Bank }\end{array}$ & $\begin{array}{l}\text { - In 2016, the discussion with the World Bank on collaborative efforts to further raising the } \\
\text { standard of AQ in ASEAN } \\
\text { - Areas of collaboration include technical assistance catering to the different capacity level of } \\
\text { ASEAN members. }\end{array}$ \\
\hline $\begin{array}{l}\text { Roundtable } \\
\text { Discussion }\end{array}$ & - With other related agencies and Big Four Audit Firms - for specific issues concerning audit. \\
\hline
\end{tabular}

\footnotetext{
${ }^{1}$ Global Public Policy Committee Working Group was the formerly name of Global Audit Quality (GAQ) Working Group
} 
The collaboration of AARG has created impact on AQ in the region. The Malaysia AOB's Annual Report of 2013 states that: "The AARG Workshop has contributed to greater consistency across the region's audit regulators and facilitated timely discussion of regional issues that have an impact on regulation of the audit profession. Through the sharing of experiences and processes, regulators are also kept abreast of developments and practices which are useful to raise the standard of audit quality in the region." (AOB, p.35) However, given these collaborative efforts, much is to be learned on how Indonesia progressed and developed individually. This is discussed in the next section.

\section{Country Efforts by Indonesia}

The paragraph above shows that the collaborative efforts may influence the policies and the internal efforts of Individual country like Indonesia to enhance its $A Q$. The areas of collaboration also include capacity building workshops and technical assistance accommodating to the differing capacity levels of ASEAN members. The AARG expects them to be at par with their neighbors' countries (www.financialmarket.theaseanbanker.com). Thus, this condition directly and/ or indirectly encourages every country's member put them into a certain pressure, whether developed or emerging countries.

The more developed countries have experience a push towards this pressure, mainly by normative and, to some mimetic pressure as well. Indonesia has not been immune from this process, and the pressure is not only because of the IFIAR and AARG's collaborative goals and targets (www.financialmarket.theaseanbanker.com), but also caused by IFAC and other international institutions such as World Bank. The World Bank has its concern about audit quality as well around the globe because it relates to the attachment of financial loan support to the conformity to its requirements regarding the nation-state institutional and organizational structure and it also proves to reflect the globalization's myth (www.pppk.kemenkeu.go.id). In order to incorporate its requirements, the emerging country tends to work by imitating the institutional structure of the most developed country which is adjusted to its condition of the country (Mayer, 1987), like Indonesia.

The accounting profession in Indonesia, in this case, the audit firms is facing growing institutional pressures from their field to incorporate the new legitimated and legitimating criterion. As mentioned above that the push toward their incorporation is expressing in growing mimetic and normative institutional pressures produced by AARG and IFIAR, as the agency of institutional carriers (DiMaggio and Powell, 1983). One of the Indonesia regulators effort to show this pressure is by restructuring the institutional drivers such as Indonesia's Finance Profession Supervisory Centre (P2PK), Indonesian Financial Service Authority (OJK), as well as establishing a new agent like the Committee of Public Accountants' Profession (KPAP). The restructuring and establishing these agents are part of imitating similar agents established by other ASEAN countries which apply it earlier. These agents are important to drive the audit quality can be implemented properly (www.pppk.kemenkeu.go.id). In addition, Indonesia is also adopting several audit quality indicators of ACRA, and issued the draft of its AQls in the year of 2016 (www.iapi.or.id). This condition can be considered as well as a process of borrowing or imitating policies occurring across the nations ( Halpin and Troyna, 1995), since it happens when organizations model other organizations 'behaviors in pursuit of legitimacy or taken-for-granted practices (DiMaggio et al., 1983; Tolbert et al., 1983). The efforts as discussed above at individual country level will be explained in detail which is focused on three areas, namely, their statutory and institutional framework, the number of accountants and professional bodies' collaboration with academic institutions.

\section{Enhancements to the Statutory and Institutional Framework}

The enhancement to statutory and institutional framework means that the way the regulatory bodies or agencies improve monitoring and enforcement of accounting and auditing mechanism, and how they put place the basic of effective regulations. There should be a consistency between the legal frameworks with the adoption of international standards to create effectiveness. The general impact of the changes caused by the new regulations or new standards is expected to modernize the regulation itself to reflect the adjusted proficient environment that has developed because of emerging worldwide economy (Hayes, 2002). Table below shows the efforts conducted by the regulators on statutory and institutional framework of Indonesia CPA profession. 
Table 3. Statutory and Institutional Framework of Indonesia CPA Profession

\begin{tabular}{|c|c|c|c|}
\hline Regulatory changes & Institutional changes & $\begin{array}{c}\text { International Standards } \\
\text { adoption }\end{array}$ & Other efforts \\
\hline $\begin{array}{l}\text { Government Rules No. } \\
\text { 20/2015: CPA Practice } \\
\text { Indonesian Law No. } \\
\text { 5/2011: Public Accountant } \\
\text { Finance Minister Decree } \\
\text { No. 17/2008: CPA Services }\end{array}$ & $\begin{array}{l}\text { The establishment of } \\
\text { Indonesian Institute of Public } \\
\text { Accountants (IAPI) } \\
\text { PPAJP changed into P2PK-2014 } \\
\text { BAPEPAM L-K changed into } \\
\text { OJK- } 2012 \\
\text { The establishment of KPAP }\end{array}$ & $\begin{array}{l}\text { ISAs (adoption in 2013): SPAP } \\
\text { Local GAAP convergence to } \\
\text { IFRS (first adoption in } 2009 \& \\
\text { full adoption in 2012) \& IFRS } \\
\text { SMEs: Local GAAP } \\
\text { Draft of Ethics Code: updated } \\
\text { in } 2017\end{array}$ & $\begin{array}{c}\text { Draft of Audit } \\
\text { Quality Indicators } \\
\text { (AQIs) }\end{array}$ \\
\hline
\end{tabular}

Source: www.iapi.or.id; www.pppk.kemenkeu.go.id

Based on the table above it may be seen that there is a great deal of progress on the enhancement of statutory and institutional framework. The main task of regulator is to prepare the formulation of policies, guidance, development and supervision of accountants. In addition, they are also the administrator of registration and licensing of public accountants and other accountants, and imposition of administrative sanctions against the professions. It also shown in table, that Indonesia has established professional body (IAPI) which have various functions whether as standard setter, supervisor of ensuring and enforcing compliance with the auditing and ethical standards, regulatory body for the profession, Continuous Professional Education (CPE) or Continuous Professional Development (CPD) provider, as well as accountants' certification examinations provider.

Indonesia adopts the International Standards on Auditing (ISAs) and the International Financial Reporting Standards (IFRS). By adopting the international standards, ASEAN members showed a high commitment to implement audit quality in order to achieve a reputable auditing profession in their respective countries (Joshi, 2008; Wang and Zhou, 2012).

\section{Mimetic Pressure and Number of Professional Accountants}

Institutional theory states that mimetic pressure motivates the country to adopt an effort when the regulators observe that other neighboring countries successfully implemented and use this similar effort or strategy for its country (Teo et al., 2003). The efforts which were conducted by the three ASEAN countries: Malaysia, Thailand and Singapore, is being noticed by Indonesia regulators that they offer certification program openly through collaborative program with leading universities. This program provides a good chance to be certified accountants, particularly for the fresh graduates to get certification together with their degree. For sure, they should follow the procedures as well as fulfilling the requirements as explained by the Vice Chief of P2PK. The regulators consider that such program has made it possible for more Indonesians to pursue a career in a recognized profession and thus help to increase the number of accountants. Moreover, Indonesia has big potential accounting graduates which has more than 35,000 alumni per year (www.aseanaccountants.org).

Thus, through IAI and IAPI the new programs prepared and started. The program is called a Professional Recognition Program for CPA which is organized by IAPI and another program which is known as the Chartered Accountants managed by IAI (www.iapi.or.id; www. http://iailounge.iaiglobal.or.id). Besides that, professional bodies have collaborated with many of the local universities to open the test center for these two programs at their respective location. These two programs are similar and comparable to the ones which being conducted in other ASEAN countries as mentioned above. The similar program which is carried out by the both professional bodies arises from referent organizations which apply institutional theory, particularly mimetic pressure, to the adoption of a variety of accounting programs and activities with both practice and moral implication.

In addition, by strengthening the accountancy profession will ensure adequate number of accountants to meet of its growing economy. Other various programs are being offered by the regulators of the country to attract, improve and promote the accountancy profession. Beside increasing the number of professional accountants, improving the capacity building of both sides (academicians, graduates and the practitioners) may fill the gap between the interests, and the market's expectation (Lee et al., 2007; Mohamed and Ahmad, 2004). An example of such effort is having harmonized international standards 
(curricula), and giving opportunities for graduates to obtain the appropriate practical experience (Dandago and Shaari, 2013; Mula, 2007; Saito et al., 2012).

Indonesia has given a serious consideration regarding the issue above. The country's regulators have created a program to scale up the number of Indonesian accountants because comparing to other countries like Malaysia, Singapore and Thailand; it only contributes less than $15 \%$ of the total accountants in ASEAN in 2015 (www.aseanaccountants.org). The figure below shows the numbers of accountants by the year (2010-2015).

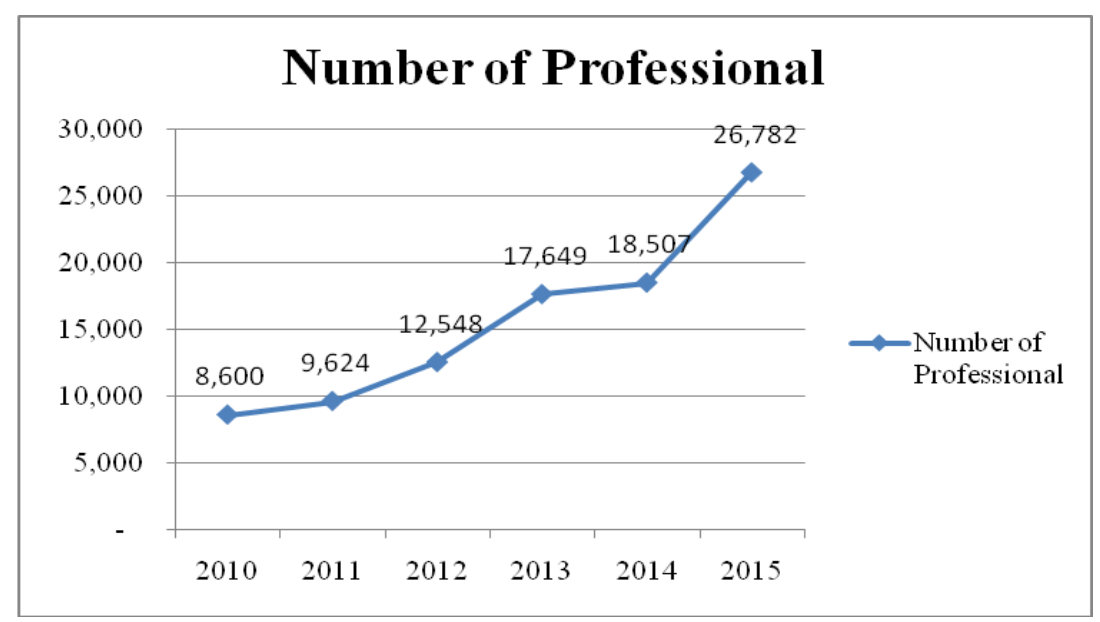

Figure 1. Numbers of accountant by Year (from 2010- 2015)

Based on the figure above, Indonesia has greatly increased the number of its accountants in 2015. This is due to two programs conducted by the professional bodies as explained on the paragraph above.

\section{Collaboration with higher educational providers}

In the case of the collaborative programs with the higher educational providers in the context of mimetic mechanism, this pressure is often generated by different organizations with which the crucial organization is associated. As mentioned above those according DiMaggio et al. (1983), when an obvious course of action is not available to an organization, it might decide to mimic others. The source of it might be from chain partners such as ACCA, IFIAR, OAB Malaysia, IFAC and others. The chain partners are not only from the regional level as mentioned previously, but also among the internal chain partners such as IAPI, IAI, Indonesian Institute of Management Accountant (IAMI) and universities.

When IFAC recommends that all countries shall adopt the international standards, they request to the country to provide certain program that involve the higher educational providers, in this case is the universities. To fill the gap between the professional practice's expectations with the universities' graduates, both (professional body and university) should have the same perspective about accounting and its profession. Therefore, the regulators put themselves as facilitators to realize it as discusses below (www.pppk.kemenkeu.go.id). This is one of the regulators' effort to face the changes.

One of the impacts of the global changes is the adoption of new standards (IFRS and ISA) which has led professional associations and regulators to collaborate with leading universities to strengthen the accountancy profession. The parties involved are committed to promote and develop the profession (www.iapi.or.id; www.iailounge.iaiglobal.or.id). They play a significant role in the formulation of the curriculum for the accounting degree programs. Among the endeavors involved are providing trainings and conducting workshops to introduce new standards to educators; offering internationally comparable accountancy education to match the contemporary requirements of the profession; revising the curricula and teaching methods based on the new principles of the latest standards, and opening a career path for accounting graduates. The table below shows several events of such collaborative programs among the parties: 
Table 4. Collaborative programs among regulators, practitioners and academicians

\begin{tabular}{cl}
\hline Professional Body & \multicolumn{1}{c}{ Description } \\
\hline IAPI & CPA test centre program at campus \\
\hline IAI & $\begin{array}{l}\text { IAI affiliated campus program; IAI -ICAEW (The Institute of Chartered Accountant in } \\
\text { England and Wales) members singed MoU about The University Students Scheme Program } \\
\text { (USS). }\end{array}$ \\
\hline
\end{tabular}

Source: www.iapi.or.id; www. http://iailounge.iaiglobal.or.id; www.aseanaccountants.org

\section{Discussions}

Based on the analysis, this study shows that the country was putting in various initiatives in relation to its $A Q$, instead of participating its role regionally among AARG countries members. Following its participation with AARG's programs, the country has issued a draft Audit Quality Indicators (AQI) in the year of 2016 as well as Code of Ethics in 2017 for the accountants. Initially, the participation of Indonesia in AARG might be motivated by mimetic pressure since the AARG as well as the other international organization which was also involved in the AQ's enhancement program such as World Bank, expect to the members to be at par among members in term of $A Q$. Thus, the country accelerates its efforts by mimicking others. As explained above, the mimetic mechanism happens when organizations model other organizations 'behaviors in pursuit of legitimacy or taken-for-granted practices (DiMaggio et al., 1983; Tolbert et al., 1983). When a clear course of action is not available to an organization, it might decide to mimic others. In other words, mimetic pressure involves the perception of some value of mimicking a behavior from other referent actors, because the behavior or form appears to be associated with effectiveness. Therefore, the evidence shows that the country is in positive direction in its quest to improve $A Q$. Beside the country's participation regionally in AARG, there are other initiatives which also conducted at the country level. This initiative can be categorized into at least four aspects: statutory and institutional framework, number of professional accountants, professional developments program and collaboration's program with universities.

\section{Impact on the Enhancements to the Statutory and Institutional Framework}

The regulators efforts on enhancement to statutory and institutional framework gave impact to the improvement and the development of $A Q$ in Indonesia. There is a progressive move away from selfregulation of auditing by the accountancy profession towards an independent regulation within a statutory framework that is now highly supervised by government regulators. The regulators have made several efforts in enhancing their statutory and institutional framework concerning audit quality due to the changes. The issuance of CPA Act No 5/ 2011 and Government Rule No 20/2015 are the great achievement to fulfill the coercive pressure from international organization that the country has to provide stronger legal backing above the Decree of Minister of Finance to enforce and ensure the effectiveness and the efficiency of the institutional drivers to perform their functions as stated by RG01. Thus, the Act and the government regulation abovementioned protect the profession legally. Another statutory effort is that the country adopts international standards. This is evidence that a country is commitment in enhancing AQ (Joshi, 2008; Wang and Zhou, 2012). However, the successful implementation of international accounting and auditing standards is very dependent on local conditions. The process of adopting standards and adapting changes has been a challenge and constrain regarding the issues of capacities of each country (Tokar, 2005).

\section{Number of Professional Accountants}

Indonesia is one of an emerging country which has big population, with more than 250 million people (www.bps.go.id). However, this societies' number is not equal to the number of Indonesian accountants and public accountants. The total number of both accountants as of March 2014 is 22.269 accountants. This is only $12.07 \%$ of total accountants in ASEAN, whereas the number of accounting graduates is 35.000 alumni per year (www.aseanaccountants.org). It should be more accountants every year if considering the accounting graduates from all universities in Indonesia (www.iaiglobal.or.id). The issue is about the 
membership problem of IAI and IAPI. Indonesia is still having "big work" to scale up and grow the number of accountants. The ratio should be appropriate, since the accountant is a guardian of business, in term of financial reporting to be more accountable and transparence.

Based on the issue explained above, at the beginning year of 2015, IAPI offers certain program of certification. IAPI introduces a new acceleration and intensive program to stimulate audit firm's staffs to becoming member of IAPI. This program especially offers to the managers and supervisors level in audit firms to get "CPA ${ }^{2}$ title". The new program of IAPI is called Professional Recognition Program for Certified Public Accountants of Indonesia (PRP CPAI) in 2015 and then changed into Recognition Prior Learning for Certified Public Accountants of Indonesia (RPL CPAI) in 2016, and the last is the conversion program from CPAl to CPA in 2017. This is an initial program for the preparation of becoming CPA. There are certain requirements that should be fulfilled by the participants. This program is successful, and during almost 2 years IAPI may increase the members more than 700 CPAI. The next steps will be offered to join one more examination to get full "CPA" title (www.iapi.or.id). It is obvious that limited numbers of accountants, Indonesia keeps making rooms for improvements and developments especially in the sense of audit quality (www.pppk.kemenkeu.go.id). The regulators work together with professional body to prepare program that increase as well as maintain the number of accountants in Indonesia, and the impact can be seen especially in the year of 2015that the number of accountants great increased.

\section{Collaboration with higher educational providers}

Another effort of the regulator is conducting collaborative activities with leading and accredited university. One example of the activities is incorporate international standards such as IFRS, ISA and the IFAC Code of Ethics in academic programs of universities throughout the country. The universities are also aware, review and update the accounting curricula of universities to incorporate with them. Teaching should focus on the practical implementation aspects of these standards using illustrations and actual case studies in Indonesia. In order to support this initiative, it will be necessary to arrange train-the-trainer programs with the participation of university and college lecturers. The impact may reduce the gap between the university output with the job expectation as stated by RG02 and RG04.

\section{Conclusions}

The basic question of this paper related to examine whether Indonesia's participation in AARG, which the main purpose of this organization is to strengthen AQ in ASEAN countries is purely part of the country's on-going efforts on $A Q$ or it is motivated by mimetic pressure to be similar to its neighbours. This can be concluded that instead of comparing Indonesia with its neighbouring countries that Indonesia is behind in terms of few aspects concerning $A Q$ including the number of accountants in the country, however the country is in fact seeing significant increase in the number of accountants since the year of 2015. Following its participation with AARG, the country has issued a draft Audit Quality Indicators (AQI) in 2016 as well as Code of Ethics in 2017 for accountants. In addition, it also indicates that there are at least three development aspects which show great note that the regulatory changes occurred are the efforts and initiatives of the regulators to enhance the $A Q$ in Indonesia. By keeping abreast of the current developments on $A Q$, changes in the institutional and regulatory frameworks, ensure that the audit quality of the country remain better and up-to date. However, in order to ensure effective regulatory developments, in this case the auditing framework, the regulators should clearly define the roles, rights, and the responsibility of all the parties involved in the AQ. In addition, in term of regional efforts level, the discussion in this paper shows how, ASEAN is closely following the efforts taken at global level by the IFIAR in improving the audit quality. However, continues improvement is still being taken by each country to enhance AQ including Indonesia.

\footnotetext{
${ }^{2}$ CPA: Certified of Professional Accountant of Indonesia. CPA is the beginning title given by the association after passing the examination of joining PRP CPA program.
} 


\section{References}

1. Adams, R. B., Hermalin, B. E., \& Weisbach, M. S. (2010). The role of boards of directors in corporate governance: A conceptual framework and survey. Journal of economic literature, 48(1), 58-107

2. Aghaei Chadegani, A. (2011). Review of studies on audit quality. 312-317.

3. Aguilera, R. V., \& Jackson, G. (2010). Comparative and international corporate governance. The Academy of Management Annals, 4(1), 485-556

4. Asian Development Bank (2003), Diagnostic Study of Accounting and Auditing Practices in Indonesia, The Asian Development Bank, Manila

5. Barley, S. R., \& Tolbert, P. S. (1991). Introduction: At the intersection of organizations and occupations

6. Beattie, V., Fearnley, S., \& Hines, T. (2010). Factors affecting audit quality in the 2007 UK regulatory environment: perceptions of chief financial officers, audit committee chairs and audit engagement partners".

7. Carruthers, B. G. (1995). Accounting, ambiguity, and the new institutionalism. Accounting, organizations and society, 20(4), 313-328

8. Centre for Audit Quality (CAQ). (2014). Approach to Audit Quality Indicator. Retrieved online from https://www.thecaq.org/caq-approach-audit-quality-indicators.

9. Claessens, S., \& Yurtoglu, B. B. (2013). Corporate governance in emerging markets: A survey. Emerging markets review, 15, 1-33

10.Covaleski, M. A., Dirsmith, M. W., \& Michelman, J. E. (1993). An institutional theory perspective on the DRG framework, case-mix accounting systems and health-care organizations.

11.Covaleski, M. A., \& Dirsmith, M. W. (1988). An institutional perspective on the rise, social transformation, and fall of a university budget category. Administrative science quarterly, 562-587.

12.DeAngelo, L. E. (1981). Auditor size and audit quality. Journal of accounting and economics, 3(3), 183-199

13.DeFond, M. L., \& Lennox, C. S. (2011). "The effect of SOX on small auditor exits and audit quality". Journal of Accounting and Economics, 52(1), 21-40.

14.Fearnley, S., Brandt, R., \& Hines, T. (2014). "The impact of changing regulation on the behavior and perception of UK Directors and auditor". Retrieved online from http://impact.ref.ac.uk/CaseStudies/ CaseStudy.aspx?ld=10898.

15.Gul, F. A., Wu, D., \& Yang, Z. (2013). Do individual auditors affect audit quality? Evidence from archival data. The Accounting Review, 88(6), 1993-2023

16. Halpin, D. and Troyna, B. (1995). 'The politics of policy borrowing', Comparative Education 31(3).

17.Hecimovic, A., Martinov-Bennie, N., \& Roebuck, P. (2009). "The force of law: Australian Auditing Standards and their impact on the auditing profession". Australian accounting review, 19(1), 1-10.

18. Humphrey, C., Loft, A., Woods, M. (2009). The global audit profession and the international financial architecture: Understanding regulatory relationships at a time of financial crisis. Accounting Organizations and Society 34, 810-825.

19.Institut Akuntan Publik Indonesia (IAPI) (2016). Laporan Tahunan 2016. Institut Akuntan Publik Indonesia.

20.International Auditing and Assurance Standard Board (IAASB). (2014). A framework for Audit Quality. Retrieved online from http://www.ifac.org.

21.International Forum of independent Audit Regulator (IFIAR). (2016). IFIAR 2015 Annual Report. Retrieved online from https://www.ifiar.org/latest-news/ifiar-2015-annual-report/.

22.Jackson, A. B., Moldrich, M., \& Roebuck, P. (2008). Mandatory audit firm rotation and audit quality. Managerial Auditing Journal, 23(5), 420-437.

23.Jo, H., \& Harjoto, M. A. (2011). Corporate governance and firm value: The impact of corporate social responsibility. Journal of business ethics, 103(3), 351-383.

24.Knechel, W. R. (2016). Audit quality and regulation. International Journal of Auditing, 20(3), 215223.

25.Lennox, C. (2009). "The changing regulatory landscape". International journal of Auditing, 13(2), 79-85. 
26.Lennox, C. S., Wu, X., \& Zhang, T. (2014). Does mandatory rotation of audit partners improve audit quality?. The accounting review, 89(5), 1775-1803.

27.Mansouri, A., Pirayesh, R., \& Salehi, M. (2009). Audit competence and audit quality: Case in emerging economy. International Journal of Business and Management, 4(2), 17.

28.Meyer, J.W. (1987). 'The world polity and the authority of the nation-state', in Thomas et al. (eds.)

29.Moore, C. B., Bell, R. G., Filatotchev, I., \& Rasheed, A. A. (2012). Foreign IPO capital market choice: Understanding the institutional fit of corporate governance. Strategic Management Journal, 33(8), 914-937.

30.Patton, M. Q. (2002). Designing qualitative studies. Qualitative research and evaluation methods, 3, 230-246.

31.Pusat Pembinaan Profesi Keuangan (PPPK) (2016). Sejarah. Berita-PPPK- Sekertariat Jenderal Kementerian Keuangan Republik Indonesia, Retrieved online from http://pppk.kemenkeu.go.id/News.

32.Teo, H. H., Wei, K. K., \& Benbasat, I. (2003). Predicting intention to adopt interorganizational linkages: An institutional perspective. MIS quarterly, 19-49.

33.Tolbert, P., and Zucker, L. "Institutional sources of change in the formal structure of organizations: The diffusion of civil service reform, 1880-1935," Administrative Science Quarterly 1983, pp. 22-39.

34.Zucker, L. G. (1987). Institutional theories of organization. Annual review of sociology, 13(1), 443464. 